\title{
The Role of the Participatory Depositor in the Governance of Islamic Banks
}

\author{
Simona Franzoni ${ }^{1} \&$ Asma Ait Allali ${ }^{1}$ \\ ${ }^{1}$ Department of Economics and Management, Brescia University, Brescia, Italy \\ Correspondence: Simona Franzoni, Department of Economics and Management, Brescia University, 25122, 50, \\ S. Chiara, Brescia, Italy. E-mail: simona.franzoni@unibs.it
}

Received: April 10, 2018

doi:10.5539/ijbm.v13n8p154
Accepted: June 4, 2018

Online Published: June 30, 2018

URL: https://doi.org/10.5539/ijbm.v13n8p154

\begin{abstract}
The aim of this paper is to verify whether participatory depositors, a special category of stakeholder that entrusts its savings to the Islamic Bank on the basis of the Profit and Loss Sharing principle, could be better protected by providing for them to be represented in the governance bodies of the Bank.

The analysis that was carried out and consideration of potential risks this category of saver could be exposed to shows the need to ensure greater protection to participatory depositors compared to other stakeholders. Three working hypotheses on the protection method to be applied are formulated.

The study was carried out on the basis of a comparative analysis of four case studies from Malaysia, Morocco, Germany and Italy respectively.

The performed analysis has led to the conclusion that the representation of participatory depositors should be provided in specific corporate governance committees.
\end{abstract}

Keywords: corporate governance, participatory depositors, loss and profit sharing principle, Islamic bank, international comparison

\section{Introduction}

The Islamic Bank is based on the precepts and principles of religious derivation that oversee the Islamic economic system. The Islamic Bank model pursues the aim of achieving adequate remuneration on investments without applying interest (prohibition of 'ribà') on loans and requires financed activities to have real assets to support them (Archer \& Rifaat, 2002; Durán \& García-López, 2012; Alam, Gupta \& Shanmugam, 2017). In the Islamic Bank, interest - which is the typical source of remuneration of financial intermediation activities at conventional banks -, is replaced by the basic Profit and Loss Sharing (PLS) principle in financed activities (Saeed 1996; Iqbal \& Llewellyn, 2002; Mirakhor \& Zaidi, 2007; Muda \& Ismail, 2010; Abdul-Rahman \& Nor, 2016). The Islamic Bank shares the risk of loss that is connected with the projects it finances. Consequently, in particular types of Islamic financing contracts, the depositor takes on the risk of being a participatory depositor, i.e. a party that entrusts its money to the Islamic Bank, with the latter managing and monitoring the raised money on the basis of the PLS principle (participation in the profits and losses of the financed project). The depositor who does not participate in the direct management of his or her savings could share not only the profits but also the losses generated by unsound choices (Van Greuning \& Iqbal, 2008; Kammer et al., 2015. The result is the depositor being a passive party with no management powers over investment and corporate governance decisions and therefore, having no powers on the selection and monitoring of projects to be financed; this occurs despite the money he/she has brought as a depositor. Participatory depositors are therefore stakeholders similar to shareholders because they invest their money in accordance with the Profit and Loss Sharing principle but are not formally recognised within the bank (Chapra \& Ahmed, 2002; Archer \& Karim, 2009; Magalhaes \& Al-Saad, 2013; Hamza, 2016).

Based on this premise and in consideration of the potential risks to which this category of saver could be exposed, this paper has set itself the task of investigating whether 'participatory depositors' might be better protected by providing for them to be represented in the governance bodies of the Islamic Bank, so they can influence decisions regarding the bank's entire business or just its investment policy concerning funds generated by the money deposited by this category of stakeholder. 
To meet this condition and thereby assign an active role to depositors in the corporate governance of the Islamic Bank, the following three types of working hypotheses are formulated. More precisely, the participatory depositors could be represented:

- In corporate governance bodies by an independent non-executive director appointed to the board of directors or supervisory board;

- In corporate governance committees by an independent, non-executive director appointed to the governance committee;

In auditing bodies in charge of managing and monitoring the bank's various investment projects, for example by an external advisor appointed to the board of directors of the companies that are the recipients of the funding.

In order to answer the research question for this study and assess the applicability of the three working hypotheses outlined above, after a brief theoretical introduction on the role of the participatory depositor in the corporate governance systems of the Islamic Bank, this paper proceeds with the comparative analysis of four case studies from Malaysia, Morocco, Germany and Italy respectively. The results allow to highlight the strengths and weaknesses in the protection of the participatory depositor and to reach some concluding reflections on whether the depositor actually needs greater protection than other categories of stakeholders and, if so, what the best solution among the three working hypotheses outlined above might be.

\section{Literature Review: The Role of the Participatory Depositor}

The Islamic Bank employs a series of financial instruments governed by different contracts in which the roles and positions of the bank and its customers depend on the nature and type of transactions that characterise the bank's money raising activities and use (Guan, 1998; Warde, 2000; Usmani, 2004; Iqbal \& Mirakhor, 2011; Harrison \& Ibrahim, 2016). In order to distinguish and group these different contracts, the elements determining the classification of these types of transaction include the Profit and Loss Sharing (PLS) principle, i.e. the joint assumption of any loss on investments made by the bank, based on the conclusion of the Islamic participatory financial contracts mudarabah and musharakah (Iqbal \& Mirakhor, 2011; Ibrahim \& Alam, 2017).

With regard to raising money, the Islamic Bank has two fundamental categories of depositor, corresponding to non-remunerative deposits and participatory deposits. In the case of non-remunerative deposits, the bank only offers secure holding of the money and helps in the management of payments (wadi'ah). These deposits do not envisage remuneration nor require the depositors to pay expenses; in its turn, the bank undertakes to return the money to depositors on the latter's demand. As for participatory deposits, the deposited money is remunerated according to the Profit and Loss Sharing principle (Iqbal \& Mirakhor, 2011; Muda \& Ismail, 2010; Ait Allali, 2016; Abdul-Rahman \& Nor, 2016). Specifically, if the deposited money is used by the bank to finance all possible uses without distinction, then the participatory deposits take the form of unrestricted accounts, whereas if the raised money is used for the financing of specific projects, then the deposits take the form of restricted accounts or investment accounts that are remunerated through participation in profits and losses (Iqbal \& Mirakhor, 2011; Usmani, 2004).

The participatory depositor of the Islamic Bank therefore features a mixture of attributes that are typical of the simple depositor-saver and shareholder-investor, but with the difference of not benefitting from all the powers that a shareholder is usually entitled to, i.e. the participatory depositors are not entitled to vote in the shareholders meeting (Chapra \& Ahmed, 2002; Usmani, 2004; El Qorchi, 2005).

This feature of the participatory depositor raises questions from the point of view of corporate governance, since the depositor has no control over the money that has been deposited in the bank, with the consequent risk of moral hazard on the part of the Islamic Bank (Chapra \& Ahmed, 2002; Hamza, 2016). Chapra (Chapra \& Ahmed, 2002) argues that insurance instruments would be sufficient to protect this category of stakeholder from risks incurred by the bank. This safeguard however is contradicted by the realistic nature of Islamic principles, which mainly feature the non application of interest and the sharing of risks. Chapra states that it is also true that the participatory depositor could be protected by setting of an effective and efficient regulation and supervision system at the level of the individual company and at the level of minimising the risks the bank itself takes.

The protection of stakeholders, at the corporate governance level of the Islamic Bank, is a central topic on which international Islamic finance supervisory institutions have issued specific guidelines. In particular, the Islamic Finance Services Boards (IFSB) document on corporate governance in 2006, 'Guiding Principles on Corporate Governance for Institutions Offering Only Islamic Financial Services (Excluding Islamic Insurance (Takâful) Institutions and Islamic Mutual Funds)', includes a specific section on investment account holders (i.e., 
participatory depositors) in which the best practices are outlined to protect the rights and economic interests of this category of stakeholder. In particular, the IFSB Standards recommend the Islamic Bank to guarantee the following for participatory depositors, with the aid of the governance committee:

- The right to monitor the trend of their investments and related risks;

- The introduction of internal procedures for investment selections;

- $\quad$ The operators' professionalism;

- The proper management of relations with participatory depositors starting from the pre-contractual stage;

- The availability of an adequate informative note on the characteristics of the relationship, the Profit and Loss Sharing method and the investment policies.

This governance committee should monitor and ensure that the management, the administrative and accounting organisation, the internal auditing system and disclosure policies are carried out in such a way as to respect and safeguard interests that are not represented in corporate bodies, with particular attention to the holders of participatory deposits. This committee, pursuant to the instructions of the IFSB, should consist of at least one member of the board of directors with executive duties, a Shariah expert - possibly a member of the Shariah Supervisory Board (whose main task is to monitor the Shariah compliance of the Islamic Bank) -, a member of the audit committee and an independent director.

The recommendations and guidelines dictated by the IFSB are a fundamental and essential objective that the Islamic Bank must achieve in order to create the conditions for good governance that can ensure its development in the international economic context, and to meet the expectations of all stakeholders and specifically of participatory depositors who, as well as sharing the risks of losses caused by the management of financed investments, entrust the bank with their savings in such a way as to respect their Islamic belief (Mollah \& Zaman, 2015).

In brief, the foregoing discussion allows elements that confirm the need to identify the role that participatory depositors, as a 'special' category of stakeholder, could play in the corporate governance of the Islamic Bank to be pinpointed for the purpose of protecting their interests in relation to the risks that are borne in the application of the Profit and Loss Sharing principle.

\section{Working Hypotheses Formulated for the Protection of Participatory Depositors}

This paper aims at understanding whether participatory depositors, given the risk to which they are exposed, might be better protected than other stakeholders by providing for them to be represented in the corporate governance of the Islamic Bank.

This paper intends to formulate a proposal by identifying three working hypotheses that will be validated or rejected with the support of case studies. These working hypotheses are as follows:

- HP1: participatory depositors could be represented in corporate governance bodies, for example by an independent and non-executive director appointed to the board of directors or supervisory board, based on the adopted corporate governance model (monistic model, horizontal dualistic model, vertical dualistic model);

- HP2: participatory depositors could be represented in specific corporate governance committees, for example by an independent, non-executive director appointed to the governance committee;

- HP3: participatory depositors could be represented in auditing bodies in charge of managing and monitoring the bank's various investment projects, for example by an external advisor appointed to the board of directors of the companies that are the recipients of the funding.

HYPOTHESIS No. 1 - Figure 1 represents the first working hypothesis, i.e. the representation of participatory depositors in the board of directors or the supervisory board, based on the corporate governance model that has been adopted by the bank. 


\section{The monistic model}

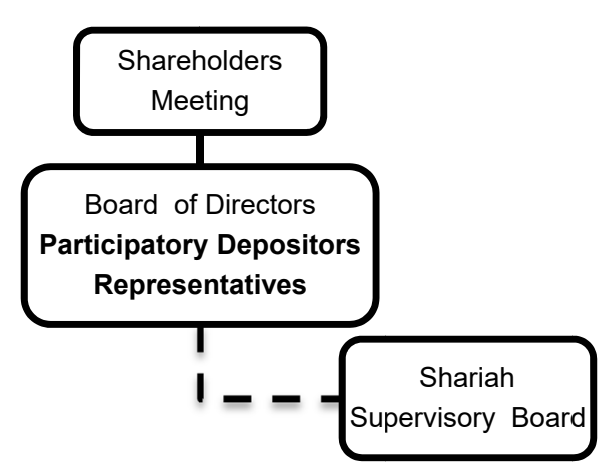

The vertical dualistic model

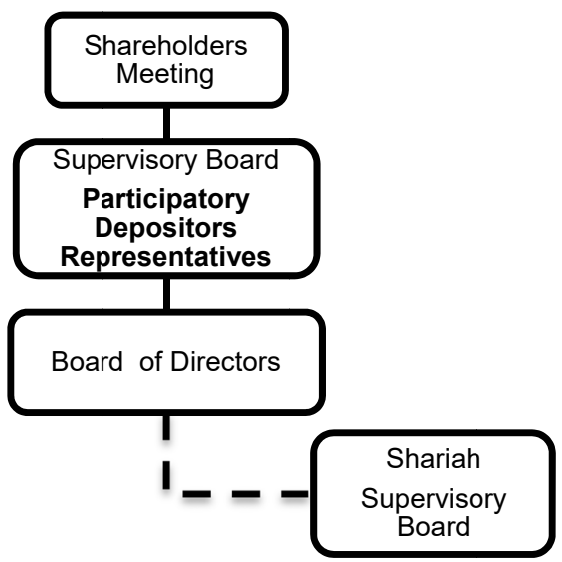

The horizontal dualistic model

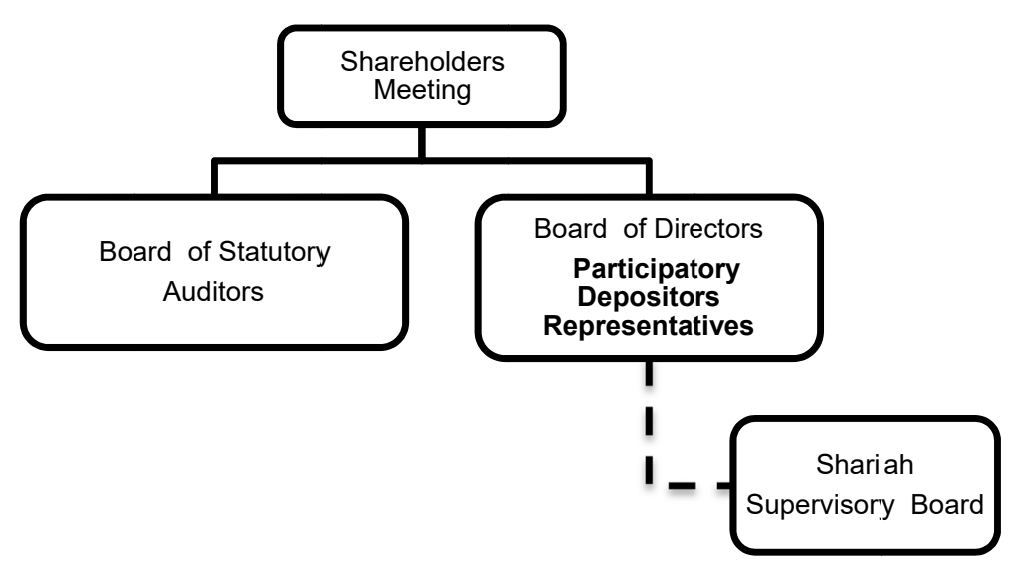

Figure 1. Representation of the participatory depositor in the monistic and dualistic models

HYPOTHESIS No. 2 - The second working hypothesis, i.e. the representation of participatory depositors in specific corporate governance committees, converges with the provisions of the IFSB that require the establishment of a governance committee aimed at the protection of stakeholders and conceived as a reference body for the supervisory authority responsible for the depositor guarantee policy.

In particular, the representation of participatory depositors by an independent non-executive director in the governance committee should ensure them greater transparency and involvement in the management and monitoring of projects that are financed by the bank (Figure 2).

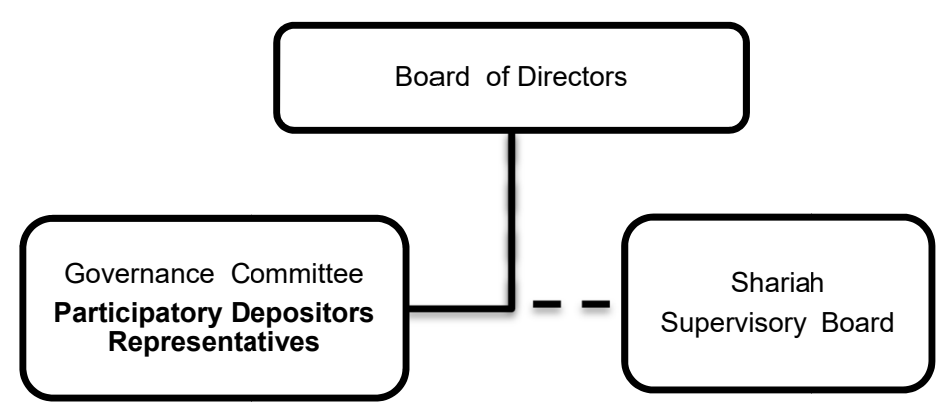

Figure 2. Representation of the participatory depositor in the governance committee. 
HYPOTHESIS No. 3 - Finally, the last working hypothesis, according to which the representation of participatory depositors by external advisors in auditing bodies in charge of managing and monitoring the bank's investment projects (Figure 3) could protect these stakeholders by directly involving them in the management and monitoring projects that have been selected and financed by the bank. This working hypothesis is inspired by the Malaysian case, where the bank chooses its own representative in the board of directors of the companies that are the recipients of the funding.

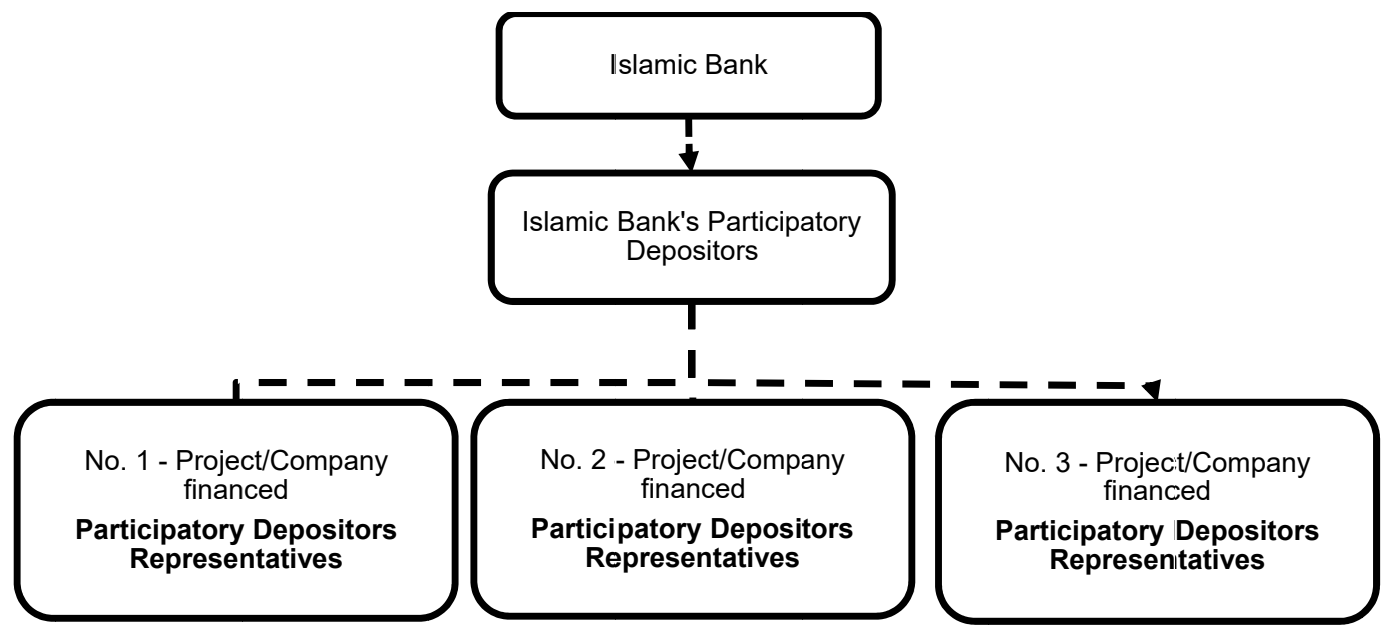

Figure 3. Representation of he participatory depositors in financed projects/companies.

\section{Methodology}

This study adopts a methodological approach based on the analysis of case studies (Yin, 2013). This qualitative methodology is mainly based on collecting information through documental analysis (Corbetta, 2003) and on semi-structured interviews conducted by administering questionnaires. Specifically, it applies a methodological approach (Corcoran, Walker \& Wals, 2004) based on legislation analysis and practices that are implemented by Islamic Banks in the selected countries in order to verify the formulated working hypotheses.

The countries selected for this study are the following:

- Malaysia and Morocco (two Muslim countries). Malaysia is characterised by the consolidated presence of Islamic finance and by a strict regulation of the Islamic finance industry, whereas Morocico is in the start-up and launch phases of its first Islamic (or participatory) Banks.

- Germany and Italy (two non-Muslim European countries). Germany is experimenting its first Islamic Bank (founded in 2015), and was chosen due to its large Muslim community and the important role it could have in the future development of Islamic finance in the Eurozone. Italy is also characterised by a large Muslim community but is still in a 'stand-by' phase because of the legal and fiscal aspects that are hindering the start-up of Islamic finance.

According to the chosen method, the case studies were conducted through (Table 1):

- Documental analysis of laws and regulations on Islamic finance in each involved country;

- Empirical survey, by collecting information made available on the websites of the banks in the four analysed countries, which is supplemented by the administration of a semi-structured questionnaire sent by e-mail to said banks and accompanied, in some cases, by interviews with the managers of the banks. 
Table 1. Sources of information of the case studies.

\begin{tabular}{|c|c|c|}
\hline $\begin{array}{l}\text { Analysed } \\
\text { countries }\end{array}$ & Documentation for the documental analysis & Documentation for the empirical analysis \\
\hline Malaysia & $\begin{array}{l}\text { Guidelines on Corporate Governance for Licensed } \\
\text { Institutions (BNM/RH/GL 001-1). } \\
\text { - Guidelines on Financial Reporting for Islamic } \\
\text { Banks (BNM/RH/GL 002-2) } 1 \\
\text { - Guidelines on Musharakah and Mudharabah } \\
\text { Contracts for Islamic Banking Institutions, } \\
\text { BNM/RH/GL/ 007-9. } \\
\text { - Islamic Banking and Takaful Department, } \\
\text { Guidelines on Corporate Governance for Licensed } \\
\text { Islamic Banks (GP1-the), BNM/RH/GL 002-1, Bank } \\
\text { Negara Malaysia. } \\
\text { - Islamic Banking and Takaful Department. } \\
\text { Guidelines on Investment account (BNM/RH/STD } \\
\text { 029-4). } \\
\text { - Shariah Governance Framework for Islamic } \\
\text { Financial Institutions (BNM/RH/GL 012-3) 1. }\end{array}$ & $\begin{array}{l}\text { - Documental analysis made available on the website of } \\
\text { Bank Islam Malaysia Berhad. } \\
\text { - Analysis of the semi-structured questionnaire sent by } \\
\text { email to sixteen Islamic Banks authorised by the Central } \\
\text { Bank of Malaysia and operating in Malaysia. }\end{array}$ \\
\hline Morocco & $\begin{array}{l}\text { - Loi No. } 103.12 \text { 'Credit institutions and } \\
\text { assimilated organizations', Dahir No. 1-14-193 du 1er } \\
\text { Rabii THE } 1436 \text { (24 december 2014). } \\
\text { - Code Marocain de Bonne Pratiques de } \\
\text { Gouvernance d'Entreprise. } \\
\text { - Dahir n.1-80-270 (du } 08 \text { avril 1981) relatif à la } \\
\text { création du Conseil supérieur et des conseils régionaux } \\
\text { des Oulémas. }\end{array}$ & $\begin{array}{l}\text { - Documental analysis made available on the website of } \\
\text { Umnia Bank (the only participatory bank out of the eight } \\
\text { authorised by the Central Bank of Morocco bank with an } \\
\text { active website at the time of the present study). } \\
\text { - Administration of the semi-structured questionnaire } \\
\text { sent by email. }\end{array}$ \\
\hline Germany & $\begin{array}{l}\text { - } \quad \text { German Stock Corporation Act (Aktiengesetz), } 10 \\
\text { May } 2016 . \\
\text { - } \quad \text { German Corporate Governance Code. }\end{array}$ & $\begin{array}{l}\text { - Documental analysis made available on the website of } \\
\text { KT Bank AG. } \\
\text { - Administration of the semi-structured questionnaire } \\
\text { sent by email. }\end{array}$ \\
\hline Italy & $\begin{array}{l}\text { - } \text { Banca d'Italia, Gomel G. (2010), Islamic finance } \\
\text { and conventional financial systems, Occasional Paper; } \\
-\quad \text { Legislative Decree no. } 6 \text { of } 17 \text { January } 2003 . \\
-\quad \text { Loi No. } 385 \text { (september 1993), Articles 5, 10, } \\
\text { 11. } \\
\text { - } \quad \text { Consob (National Commission for Companies } \\
\text { and Stock Exchange), Alvaro S. (2014), Islamic finance } \\
\text { in the Italian legal and economic context, Paper no. } 6 . \\
\text { - } \quad \text { Articles } 2549 \text { and ff. of the Civil Code. }\end{array}$ & $\begin{array}{l}\text { - Documental analysis made available on the websites } \\
\text { of the three most important banking groups in Morocco with } \\
\text { branches operating in Italy: AttijariWafa Banque, Banque } \\
\text { Populaire du Maroc and Banque Marocaine du Commerce } \\
\text { Extérieur. } \\
\text { - Administration of the semi-structured questionnaire } \\
\text { sent by email to the three most important banking groups in } \\
\text { Morocco with branches operating in Italy. AttijariWafa } \\
\text { Banque, Banque Populaire du Maroc and Banque Marocaine } \\
\text { du Commerce Extérieur. }\end{array}$ \\
\hline
\end{tabular}

The following section will illustrate the results of the comparative analysis of the examined cases in order to verify the research question for this study.

\section{Results: A Comparative Analysis of the Examined Cases}

The main objective of this analysis is to understand whether participatory depositors, given the risk to which they are exposed, could be better protected than other stakeholders by providing for them to be represented in the governance bodies of the Islamic Bank so as to have an active role in the corporate governance of the Islamic Bank.

To analyse the three hypotheses formulated on the matter, this section presents the comparative analysis of the examined cases, with reference to the Islamic Bank regulation system and the practices which have been adopted by each examined country. Table 2 is an overview of laws and regulations and of corporate governance structures. 
Table 2. Comparative analysis of the examined cases. Malaysia, Morocco, Germany and Italy.

\begin{tabular}{|c|c|c|c|c|}
\hline & Malaysia & Morocco & Germany & Italy \\
\hline Legislation on Islamic Banks & $\mathrm{X}$ & $\mathrm{X}$ & & \\
\hline National Shariah Compliance Authority & $\mathrm{X}$ & $\mathrm{X}$ & & \\
\hline Shariah supervisory board/Shariah committee/Conformity function & $\mathrm{X}$ & $\mathrm{X}$ & & \\
\hline Ethics council/Advisory council & & & $\mathrm{X}$ & \\
\hline Principle implementation committee & & & $\mathrm{X}$ & \\
\hline Self-regulation Code/Best practices & $\mathrm{X}$ & $\mathrm{X}$ & $\mathrm{X}$ & $\mathrm{X}$ \\
\hline Nominating Committee & $\mathrm{X}$ & $\mathrm{X}$ & $\mathrm{x}$ & $\mathrm{X}$ \\
\hline Remuneration Committee & $\mathrm{X}$ & $\mathrm{X}$ & $\mathrm{X}$ & $\mathrm{X}$ \\
\hline Risk Management Committee & $\mathrm{X}$ & $\mathrm{X}$ & $\mathrm{X}$ & $\mathrm{X}$ \\
\hline Audit Committee & $\mathrm{X}$ & $\mathrm{X}$ & $\mathrm{X}$ & $\mathrm{X}$ \\
\hline Governance Committee & & $\mathrm{X}$ & & \\
\hline Senior Management & $\mathrm{X}$ & & & \\
\hline Board Representative & $\mathrm{X}$ & & & \\
\hline Board Investment Committee & $\mathrm{X}$ & & & \\
\hline
\end{tabular}

In particular, it was found that there is a greater number of corporate governance bodies and committees linked to the specific nature of Islamic Banks in Muslim countries. Indeed, in the case of Malaysia and Morocco, the existence of specific legislation for the Islamic Banking industry makes it possible to recognise both religious principles and consequent corporate governance specificities in the financial instruments adopted by the Islamic finance model. The presence of a legislation that recognises the principles and the peculiarities of Islamic finance creates the conditions for developing a strategy based on the integration of the Islamic finance system and the conventional finance system. Such integration was found in the case of Malaysia, a country that recognised and integrated Islamic finance into its own regulatory system for finance as early as the Eighties. In the future, such integration could also take place in Morocco since this country, with its new banking law no. 103.12, 'Credit institutions and organisation assimilates', has provided for the inclusion of (Islamic) participatory banks in its banking system. The two non-Muslim European countries that were considered, i.e. Germany and Italy, have no legislation dedicated to Islamic Banks.

Table 2 shows the lack of a national Shariah compliance authority in Germany and Italy and the presence of such authority in Malaysia and Morocco (the systems of Shariah supervision are included in the bodies of regulations of these two countries). In the latter countries, Shariah supervision of the Islamic finance industry is entrusted to a single national authority, the National Shariah Advisory Council in Malaysia and le Conseil supérieur des oulémas in Morocco. The national authority is responsible for examining and validating the compliance of new products and programmes proposed by banking institutions and by takâful (Islamic insurance) companies with Shariah, as well as providing advice on how to create these products. The intervention of the national authority for the Shariah supervision system makes it possible to live through and survive situations of uncertainty and to harmonise the interpretative criteria of religious compliance of Islamic financial instruments, creating suitable conditions for the growth and success of the Islamic finance model.

This decision to centralise Shariah compliance control activities resolves the issue of differing interpretations and opinions (fatawa) that may be issued by Islamic scholars with regard to a given operation. Indeed, the existence of different Islamic legal schools gives rise to different evaluations, despite the uniqueness of the sources of the Muslim religion, i.e. the Koran and the Sunna. This situation limits the development of Islamic finance in relation to the homogenisation and standardisation of Shariah compliant products and, above all, to regulation instruments. In this way, the so-called 'Shariah risk', i.e. the risk that a transaction judged to be Shariah compliant by the scholars of an Islamic Bank may be unlawful according to the scholars of another Islamic Bank, is prevented, despite the fact that both banks operate in the same country (Grais \& Pellegrini, 2006; Casper, 2012; Ginena, 2014). As far as the two European cases are concerned, there is clearly no central authority to which to entrust this function.

In order to be compatible with the Shariah and be a Shariah compliant company, the Islamic Bank must undergo a Shariah supervision process aimed at verifying its respect of the fundamental principles of the Islamic economic system. Supervision is carried out by the Shariah Supervisory Board (SSB), which may be internal or external to the bank depending on the regulatory context of the country where the bank is based. The SSB consists of experts in Islamic law and specifically of 'figh al-muamalat', Islamic commercial law, and has the 
task of monitoring the Shariah compliance of the Islamic Bank in its business activities, products and services, with the help of the guidelines and standards that have been provided by the Accounting and Auditing Organisation for Islamic Finance Institutions (AAOIFI) and the IFSB. The SSB generally consists of a minimum of three to a maximum of seven members who are experts in Islamic law, as well as external experts who can be consulted on economic, financial, banking matters, as well as for the engineering of new Shariah compliant products. The SSB must be autonomous and independent from the bank and the corporate bodies it renders services to. In the face of this independence and of the discretionary power granted to the members of the SSB, there are specific ethical and professional obligations and rules of conduct that must be adhered to, as set out in appendix three of the guidelines on Shariah governance issued by the IFSB in 2009. These requirements are independence, personal responsibility, care and conscientiousness, confidentiality, professional diligence and disciplinary sanctions.

The Shariah Supervisory Board performs the following three principal functions (Grais \& Pellegrini, 2006; Casper, 2012, Ginena \& Hamid, 2015; Mohamad, Sori \& Rasid, 2017):

- Certification function;

- Supervisory and, partially, auditing function;

- Advisory function.

The certification function of the SSB is considered the most relevant for the Islamic Bank, as it is necessary to prove the bank's religious integrity and for it to have a good reputation. The certification takes place through the discussion and issuance of opinions on the effective compatibility of the implemented transactions and of the various Islamic financial products that are offered with the Shariah's approval. The issued opinions are legal opinions which are not considered a source of Islamic law but whose value partly depends on the authoritativeness of the scholars that issue them; these opinions therefore become binding for the Muslims that recognise the authority of these scholars. The second function, which in part accompanies the process of certification, is the supervisory function, which consists in thoroughly verifying that all created or marketed transactions and products comply with Islamic finance principles (absence of ribà, gharar, and maysir). Such supervision also includes checking whether the subject of the investments is compatible with the dictates of the Shariah (prohibition of pork, alcohol, weapons, tobacco, gambling and pornography). This supervision monitors the business of the Islamic Bank on the whole and according to several scholars and in this process the SSB is required to ascertain that the revenue of the Islamic Bank has been generated by investments and activities that are permitted under Sharia law. In case of transactions infringing the principles of the Shariah, the SSB must develop and propose alternative solutions. Such a complex supervision activity requires the members of the SSB to be highly qualified and competent not only in Islamic law, but also in economic and financial matters. Finally, the Shariah Supervisory Board carries out advisory activities or, better yet, performs an advisory function. On request of the management and stakeholders of the Islamic Bank, the SSB can also express opinions on the Shariah compliance of new proposals for financial products, investment policies or marketing strategies.

The three main functions (certification, supervisory and advisory) that are carried out by the SSB are important and essential for the implementation of good corporate governance aimed at respecting the principles of the Shariah. Although the SSB is a fundamental part of the Islamic Bank, its recognition and integration into European and conventional corporate governance models whose regulations are out of step with the provisions of Islamic finance, is still difficult.

Unlike the Islamic regulatory contexts that have been analysed, in which Shariah supervisory bodies are formally recognised, in conventional regulatory contexts the recognition and inclusion of these bodies into the corporate governance of the banks is often more difficult. Conventional regulatory contexts include bodies and committees with specific powers that are in charge of management and control, and the possible introduction of the Shariah Supervisory Board could create redundancy and the overlapping of bodies with the same functions. To solve this issue, for example, KT Bank AG, a recently established Islamic Bank in Germany, opted for the setting up of an Ethics Council that performs the same functions as the Shariah Supervisory Board and is governed by the guidelines and internal regulations of the bank. It is appointed by the board of directors and its opinions on Shariah compliance of the bank's financial products are not binding for the board of directors, which remains responsible for the management and control of the bank. In the case of Germany, in addition to the Ethics Council in charge of the Shariah supervision function and in line with AAOIFI's Standards on corporate governance (1999), this study has found another Internal Shariah Auditing Body, the Prinzipien Umsetzung Komitees (PUK, meaning 'principle implementation committee'), which is subordinate to the board of directors and acts as a link between the latter and the Ethics Council and carries out internal auditing activities aimed at 
verifying compliance with decisions made by the Ethics Council. Consequently, it is noted that the inclusion of the SSB in the corporate governance of Islamic Banks operating in conventional contexts is possible, provided that the powers and functions of governance bodies that have been envisaged by the reference legislation are respected.

All the cases presented a self-regulatory code that recommends a series of principles of good corporate governance and the institution of a number of committees to assist management, carry out checks and protect the stakeholders in the company. These committees include the nominating committee, the remuneration committee, the risk management committee and the audit committee. Germany and Italy envisage neither the governance committee recommended by the Moroccan self-regulatory code, which has the main task of ensuring the implementation of good practices by governance bodies, nor a senior management body like the one in Malaysia that is responsible for the development and implementation of the operational policies that govern the management of investment accounts such as participatory deposits.

In the case of Malaysia, the guidelines on Islamic participatory financial contracts (musharakah and mudarabah) establish two committees, i.e. the Board Representative Committee and the Board Investment Committee. The main task of the former is safeguarding the interests and investments of the Islamic Bank at the financed company, whereas the latter has the main task of supporting the board of directors of the Islamic Bank in the management of investment accounts.

The analysis shows the lack of provisions on Islamic finance and related bodies in Italy, due to this country lacking an adequate legislation on the matter, despite the demands coming from different economic and financial operators, studies (Banca d'Italia, 2010; Consob, 2014),academia and banking associations that show their interest in Islamic finance. Basically, these studies reveal that the introduction of Islamic Banks in Italy can only be achieved after an integration of regulatory and fiscal provisions and the compatibility requirements of Islamic financial products with Italian legislation in terms of accounting, communication, distribution and operators' training.

Italy's openness to Islamic finance could lead to the expansion of the financial market and the type of services to be offered to a specific target group - such as Muslims in Italy - that is interested in investing in Shariah compliant financial products.

\section{Discussion}

The analysis of corporate governance rules, regulations and guidelines for the protection of stakeholders as well as shareholders in the countries that were considered in this study, clearly shows the need to provide for participatory depositors to be represented in the corporate governance of the Islamic Bank, since they are a category of stakeholders that deserves to be better protected.

An analysis of three working hypotheses regarding possible methods of representation of participatory depositors in the Islamic Bank will now be presented in order to identify the one that could best meet participatory depositors' need for protection in countries that have a strict regulation on the subject in place, as well as in those that do not, in countries that recognise Islamic finance in their own financial regulatory system and in those that still do not do so.

Hypothesis No. 1: participatory depositors could be represented in corporate governance bodies, for example by an independent and non-executive director appointed to the board of directors or supervisory board, based on the adopted corporate governance model (monistic model, horizontal dualistic model, vertical dualistic model).

The representation of participatory depositors in corporate governance bodies could be a costly solution, 'excessive' and in some respects discriminatory with respect to other stakeholders who have equally important interests in the bank, such as the workforce in the German corporate governance system, where the principle of co-determination applies to companies with more than 500 employees.

It should also be noted that there are countries, such as Malaysia, that have a strict regulation focused on the identification of a number of bodies and committees (senior management, board representative, board investment committee) with management and monitoring tasks of investments underlying the participatory deposits. Direct involvement of participatory depositors - through representatives in the corporate governance bodies of the bank - in the management of projects that have been selected by the board of directors and financed with their savings could therefore be redundant if not wisely governed.

According to Chapra and Ahmed (2002), the inclusion of participatory depositors' representatives in the board of directors to protect their interests and influence the decisions of the board through their representatives' votes is considered a difficult and expensive path for both the bank and the depositors. 
In essence, even if this working hypothesis is one of the most ambitious solutions to protect the interests of participatory depositors, it is costly, challenging and problematic in relation to the mode of selecting representatives.

Hypothesis No. 2: participatory depositors could be represented in specific corporate governance committees, for example by an independent, non-executive director appointed to the governance committee.

The identification of an independent, non-executive director who may represent the interests of participatory depositors in a specific committee is in line with the corporate governance guidelines issued by the IFSB in 2006. The guidelines recommend the establishment of a special governance committee, mainly for the protection of stakeholders as well as shareholders, with particular attention to holders of participatory deposits. It is obvious that in order to effectively achieve the objectives of IFSB's recommendations for the protection of stakeholders as well as shareholders, the governance committee should necessarily include independent, non-executive directors as representatives of participatory depositors.

In Morocco, the creation of a governance committee (body established before the approval of the law that introduced participatory banks) is recommended by the self-regulatory code, which gives this committee the main task of ensuring that governance bodies really implement good practices. Therefore, for Morocco, this working hypothesis could be implemented by including participatory depositors' representatives in the governance committee envisaged by Moroccan best practices and applicable in participatory banks.

The inclusion of participatory depositors' representatives in specific corporate governance committees may be less invasive than Hypothesis 1, as it would not change the composition of the governance bodies (board of directors and supervisory body).

This proposal would strengthen the procedures and measures undertaken by the Islamic Bank in order to protect the interests of stakeholders as well as shareholders.

Hypothesis No. 3: participatory depositors could be represented in auditing bodies in charge of managing and monitoring the bank's various investment projects, for example by an external advisor appointed to the board of directors of the companies that are the recipients of the financing.

The proposal for the participatory depositors involved in investment projects financed by the bank to be represented by an external advisor appointed to the board of directors of companies that receive the funding, finds a certain correspondence in the Malaysian case study. Malaysian guidelines on Islamic participatory financial contracts - such as musharakah and mudarabah, where the bank participates as a partner or provider of money in projects that will be directly managed by entrepreneurs that are its clients - provide for the possibility of the Islamic Bank to choose its own institutional representative board (board representative), appointed by the board of directors, at the financed company, with the objective of protecting the bank's interests through active and direct participation in the management of the investment.

From the viewpoint of good governance of the financed activities and simultaneous protection of the interests of the parties directly involved in the participatory contracts, this proposal could be extended to participatory depositors. This could also happen in Morocco, where the legislation requires participatory deposits in the Islamic Bank to be organised into investment portfolios. Based on these investment portfolios, external advisors could be appointed as representatives of the participatory depositors of the bank at the financed companies through the investment portfolios in which they are partners.

Compared to the two previous hypotheses, the implementation of this third hypothesis could be more effective in terms of direct involvement of participatory depositors in the protection of their own money, but could also be complex to apply due to the large number of projects simultaneously financed by the same bank.

\section{Conclusion and Implications}

This paper has studied and analysed in depth Islamic finance and the development of the Islamic Bank model in Muslim contexts (Malaysia and Morocco) as well as in Western contexts (Germany and Italy).

In particular, the analysis focused on Islamic Banks' corporate governance guidelines in each of the analysed countries, paying attention to the protection of the interests of participatory depositors. Based on the analysis and in consideration of the potential risks to which this category of saver could be exposed, the need to ensure greater protection to participatory depositors, compared to other stakeholders, is perceived.

Three working hypotheses were formulated as to how to protect the interests of this special category of stakeholders. The first proposed working hypothesis focuses on the representation of participatory depositors in corporate governance bodies. The second working hypothesis provides for the representation of participatory 
depositors in specific corporate governance committees (for example, independent, non-executive directors appointed to the governance committee). Finally, the third working hypothesis proposes participatory depositors to be represented in investment projects financed by the bank by an external advisor appointed to the board of directors of the companies that receive the funding.

The analysis focused on four selected case studies with reference to the three working hypotheses and lead to the conclusion that it is necessary to provide for participatory depositors to be represented in specific corporate governance committees.

The second working hypothesis is therefore validated. It could be applied universally to all the studied cases without interfering with the corporate governance model provided by the different national legislations.

This solution is also in line with the IFSB's guidelines, which recommend the establishment of a governance committee for the protection of stakeholders as well as shareholders. The increased protection of the interests of participatory depositors could encourage the presence of active interlocutors and the establishment of relationships of trust as well as a greater propensity, on their part, to deposit their savings based on the Profit and Loss Sharing principle.

In conclusion, the protection of participatory depositors will become more and more important in the near future due to the powerful presence of the Muslim community in the world and the growing orientation of companies towards the satisfaction of their main stakeholders from the standpoint of corporate social responsibility. The participation of participatory depositors in the governance committee of Islamic Banks would lead to the creation of a relationship based on transparency and trust among the parties, thus favouring the establishment of a durable relationship that contributes to careful management and the fulfilment of both economic and social responsibilities.

\section{References}

Abdul-Rahman, A., \& Nor, S. M. (2016). Challenges of profit-and-loss sharing financing in Malaysian Islamic banking. Geografia-Malaysian Journal of Society and Space, 12(2), 39-46.

Ait Allali, A. (2016). Corporate Governance and Corporate Social Responsibility in Islamic Banking: The Case of the Moroccan Banks in Italy. European Journal of Islamic Finance, 4, 1-10. http://dx.doi.org/10.13135/2421-2172/1642

Alam N., Gupta, L., \& Shanmugam, B. (2017). Prohibition of Riba and Gharar in Islamic Banking. In N. Alan, L. Gupta \& B. Shanmugam, (Eds.), Islamic Finance. A Practical Perspective (pp. 35-53). Cham: Palgrave Macmillan. http://dx.doi.org/10.1007/978-3-319-66559-7

Alvaro, S. (2014). La finanza islamica nel contesto giuridico ed economico italiano. Commissione Nazionale per le le Società e la Borsa. Quaderni Giuridici, 6, 1-20. Retrived from: http://www.consob.it/documents/11973/201676/qg6.pdf/6e7aeadd-cfe3-4d72-90b6-b4c4ea683f0e

Archer, S., \& Karim, R. A. A. (2009). Profit-sharing investment accounts in Islamic banks: Regulatory problems and possible solutions. Journal of Banking Regulation, 10(4), 300-306. https://doi.org/10.1057/jbr.2009.9

Archer, S., \& Rifaat, A. K. (2002). Islamic finance. Innovation and growth. London: Euromoney and AAOIFI.

Casper, M. (2012). Sharia Boards and Sharia Compliance in the Context of European Corporate Governance. SSNR working paper. Munster: Centre for Religion and Modernity. Retrieved from https://papers.ssrn.com/sol3/papers.cfm?abstract_id $=2179412$

Chapra, M. U., \& Ahmed, H. (2002). Corporate Governance in Islamic Financial Institution. The Islamic Research and Teaching Institute (IRTI). Occasional Paper, 93, 43-45.

Corbetta, P. (2003). Social research: Theory, methods and techniques. London: Sage publications. http://dx.doi.org/10.4135/9781849209922

Corcoran, P. B., Walker, K. E., \& Wals, A. E. (2004). Case studies, make-your-case studies, and case stories: a critique of case-study methodology in sustainability in higher education. Environmental Education Research, 10(1), 7-21.

Durán, J. J., \& García-López, M. J. (2012). Co-Evolution of Institutional Changes and Financial Services Integration. International Journal of Business and Management, 7(13), 49-74. http://dx.doi.org/10.5539/ijbm.v7n13p49

El Qorchi, M. (2005). Islamic finance gears up. Finance and Development, 42(4), 46-52. 
Ginena, K. (2014). Sharī 'ah risk and corporate governance of Islamic banks. Corporate Governance, 14(1), 86-103. https://doi.org/10.1108/CG-03-2013-0038

Ginena, K., \& Hamid, A. (2015). Foundations of Shari'ah governance of Islamic banks. Cornwall, Uk: John Wiley \& Sons. https://doi.org/10.1002/9781119053507.ch2

Gomel, G. (2010). Finanza Islamica e sistemi finanziari convenzionali. Tendenze di mercato, profili di supervisione e implicazioni per le attività di banca centrale. Questioni di Economia e Finanza, Banca d'Italia, 73, 1-50. Retrived from: https:/www.bancaditalia.it/pubblicazioni/qef/2010-0073/index.html

Grais, W., \& Pellegrini, M. (2006). Corporate governance and Shariah compliance in institutions offering Islamic financial services. World Bank Policy Research, Working Paper No. 4054. Retrieved from http://hdl.handle.net/10986/8901

Guan, L. K. (1998). Book Review: Islamic Banking System: Concepts \& Applications. Asia Pacific Journal of Management, 15(1), 104-105. https://doi.org/10.1023/A:1015421027039

Hamza, H. (2016). Does investment deposit return in Islamic banks reflect PLS principle? Borsa Istanbul Review, 16(1), 32-42. https://doi.org/10.1016/j.bir.2015.12.001

Harrison, T., \& Ibrahim, E. (2016). Islamic Finance - Principles, Performance and Prospects. Basingstoke, UK: Palgrave Macmillan. https://doi.org/10.1007/978-3-319-30918-7

Ibrahim, M. H., \& Alam, N. (2017). Islamic economics and Islamic finance in the world economy. The World Economy, 41(3), 668-673. https://doi.org/10.1111/twec.12506

IFSB (2006). Guiding Principles on Corporate Governance for Institutions Offering only Islamic Financial Services (Excluding Islamic Insurance (Takaful) Institutions and Islamic Mutual Funds). Retrieved fromhttps://ifsb.org/published.php

Iqbal, M., \& Llewellyn, D. T. (2002). Islamic banking and finance: new perspectives on profit sharing and risk. Cheltenham, UK: Edward Elgar Publishing.

Iqbal, Z., \& Mirakhor, A. (2011). An introduction to Islamic finance: theory and practice. Singapore: John Wiley \& Sons. https://doi.org/10.1002/9781118390474.ch2

Kammer, M. A., Norat, M. M., Pinon, M. M., Prasad, A., Towe, M. C. M., \& Zeidane, M. Z. (2015). Islamic finance: Opportunities, challenges, and policy options. International Monetary Fund, 15, 1-87.

Magalhaes, R., \& Al-Saad, S. (2013). Corporate governance in Islamic financial institutions: the issues surrounding unrestricted investment account holders. Corporate Governance: The international journal of business in society, 13(1), 39-57. https://doi.org/10.1108/14720701311302404

Mirakhor, A., \& Zaidi, I. (2007). Profit-and-loss sharing contracts in Islamic finance. In M. K. Hassan \& M. K. Lewis, (Eds.), Handbook of Islamic Banking (pp. 49-63). Cheltenham, UK: Edward Elgar Publishing.

Mohamad, S., Sori, Z. M., \& Rasid, M. E. S. (2017). Shariah boards: practical challenges for Islamic financial institutions. In M. Ariff \& S. Mohamad, (Eds.), Islamic Wealth Management: Theory and Practice (pp. 71-82). Cheltenham, UK: Edward Elgar Publishing.

Mollah, S., \& Zaman, M. (2015). Shari'ah supervision, corporate governance and performance: Conventional vs. Islamic banks. Journal of Banking \& Finance, 58, 418-435. https://doi.org/ 10.1016/j.jbankfin.2015.04.030

Muda, R., \& Ismail, A. G. (2010). Profit-loss sharing and value creation in Islamic banks. Journal of Business and Policy Research, 5(2), 262-281.

Saeed, A. (1996). Islamic banking and interest: A study of the prohibition of riba and its contemporary interpretation. Leiden, Netherlands: Brill.

Usmani, T. (2004). An introduction to Islamic finance. Karachi: Arham Shamsi.

Van Greuning, H., \& Iqbal, Z. (2008). Risk analysis for Islamic banks. Herdon, VA: World Bank Publications. https://doi.org/10.1596/978-0-8213-7141-1

Venardos, A. M. (2005). Islamic Banking in Malaysia. In A. M. Venardos, (Ed.), Islamic Banking and Finance in South-East Asia: Its Development and Future (pp. 154-171). Singapore: World Scientific Publishing Co. Pte. Ltd.

Warde, I. (2000). Islamic finance in the global economy. Edinburgh: Edinburgh University Press. http://doi.org/10.3366/edinburgh/9780748612161.003.0006 
Yin, R. K. (2013). Case study research: design and methods. Los Angeles, USA: Sage.

\section{Copyrights}

Copyright for this article is retained by the author(s), with first publication rights granted to the journal.

This is an open-access article distributed under the terms and conditions of the Creative Commons Attribution license (http://creativecommons.org/licenses/by/4.0/). 